\title{
Pemanfaatan E-Commerce Untuk Pemasaran Kopi UD. Topeng Kona Coffee Roastery Bondowoso
}

\author{
Dedy Wijaya Kusuma ${ }^{1}$, Mustofa ${ }^{2}$, Helmi Agus Salim ${ }^{3}$ \\ ${ }^{1}$ STIE Mandala Jember \\ ${ }^{2}$ STIE Mandala Jember \\ ${ }^{3}$ STIE Mandala Jember \\ Email: dedy@stie-mandala.ac.id
}

\begin{abstract}
Perkembangan teknologi, komunikasi dan komputer mendorong pertumbuhan perekonomian masyarakat yang mengembangkan bisnis secara online. Perdagangan menggunakan media internet merupakan peluang usaha yang menjanjikanuntuk dikembangkan. Kemudahan proses transaksi dan dukungan teknologi membuat perdagangan menggunakan media internet (e-commerce) berkembang pesat. UD. Topeng Kona Coffee Roastery merupakan usaha kecil yang mengolah biji kopi untuk siap dikonsumsi. Namun pemasaran produk kopi dengan merek Topeng Kona ini masih dilakukan secara konvensional, sehingga produk kopi ini kurang dikenal oleh masyarakat luas karena kurangnya promosi. Karena kendala pemasaran dan promosi ini maka usaha kecil tersebut kurang berkembang. Melihat trend e-commerce yang banyak diminati oleh para pembeli ini, maka produk kopi Topeng Kona yang dihasilkan oleh UD. Topeng Kona Coffee Roastery ini dapat dipasarkan menggunakan e-commerce sehingga usaha kecil ini dapat berkembang.
\end{abstract}

Keywords: pemasaran, e-commerce, perluasan pemasaran, promosi produk.

\section{PENDAHULUAN}

Perkembangan teknologi, komunikasi dan komputer mendorong pertumbuhan perekonomian masyarakat yang mengembangkan bisnis secara online [1]. Perkembangan perangkat komunikasi yang membuat setiap orang yang memiliki smartphone terhubung dengan media internet membuat semakin mudah calon pembeli untuk mencari barang yang diinginkan melalui perangkat komunikasi mereka [2]. Sehingga bisnis online ini merupakan sebuah peluang yang sangat menjanjikan untuk dikembangkan [3][4].

Usaha kecil yang dijalankan oleh UD. Topeng Kona Coffee Roastery merupakan usaha rumah tangga yang memproduksi kopi dengan merek Topeng Kona. Produksi kopi Topeng Kona berjenis Arabika dan Robusta yang dipilih dari biji kopi pilihan yang telah masak dan diroasting guna meningkatkan cita rasa dan aroma kopi sehingga menjadi kopi yang berkualitas. UD. Topeng Kona Coffee Roastery mempekerjakan 5 orang pekerja dengan modal awal sekitar 50 jutaan. 
Untuk produksi tiap bulannya membutuhkan bahan baku sekitar 5 kwintal berbagai varian kopi. Namun penjualan produk kopi Topeng Kona ini masih rendah karena masih dilakukan secara konvensional. Rendahnya penjualan produk kopi Topeng Kona ini mengakibatkan UD. Topeng Kona Coffee Roastery sangat sulit mengembangkan usahanya. Dari permasalahan tersebut perlu dilakukan penjualan produk menggunakan media internet (e-commerce), sehingga pelaksanaan program kemitraan masyarakat ini bertujuan untuk menerapkan e-commerce terhadap penjualan produk kopi tersebut.

Pada penerapan e-commerce terhadap produk kopi ini maka perlu diberikan wawasan pada pelaku usaha untuk mempertahankan kualitas produk karena berhubungan terhadap kepercayaan pembeli, memberikan informasi lengkap dan cepat, keterbukaan terhadap informasi dari pelanggan dan adanya kupon dan diskon bagi pelanggan tetapnya [6][7]. Transparansi informasi pengiriman produk, trace keberadaan barang yang dikirimkan dan kerjasama yang baik antara penjual dan pembeli harus terjaga dengan baik. Kewaspadaan terhadap penipuan secara online juga merupakan informasi yang perlu diberikan pada pelaku usaha pada pelaksanaan program kemitraan masyarakat ini. Sehingga diakhir pelaksanaan program kemitraan masyarakat ini UD. Topeng Kona Coffee Roastery memahami peluang usaha secara online, dapat bersaing dengan sehat, mendapat kepercayaan dari pelanggannya, dapat mengantisipasi penipuan secara online dan dapat mengembangkan usahanya.

\section{TARGET DAN LUARAN}

Adapun target dari pelaksanaan program kemitraan masyarakat ini adalah sebagai berikut:

a. Melakukan transfer teknologi kepada mitra tentang pemanfaatan media internet sebagai media promosi sekaligus media pemasaran produk mitra.

b. Meningkatkan pengetahuan mitra tentang promosi menggunakan media internet sebagai media promosi sekaligus media pemasaran produk mitra sehingga akan meningkatkan pendapatan mitra.

c. Meningkatkan pengetahuan mitra tentang promosi dan penjualan produk mitra menggunakan gerai online.

Sedangkan luaran dari pelaksanaan program kemitraan masyarakat ini adalah:

a. Pemanfaatan aplikasi e-commerce UD. Topeng Kona Coffee Roastery untuk promosi dan pemasaran produk kopi Topeng Kona.

b. Publikasi tentang dampak yang ditimbulkan pada pelaksanaan program kemitraan masyarakat ini terhadap pendapatan mitra.

III. METODE PELAKSANAAN

Pelaksanaan program kemitraan masyarakat ini digambarkan ke dalam diagram alir pada gambar 1 . 


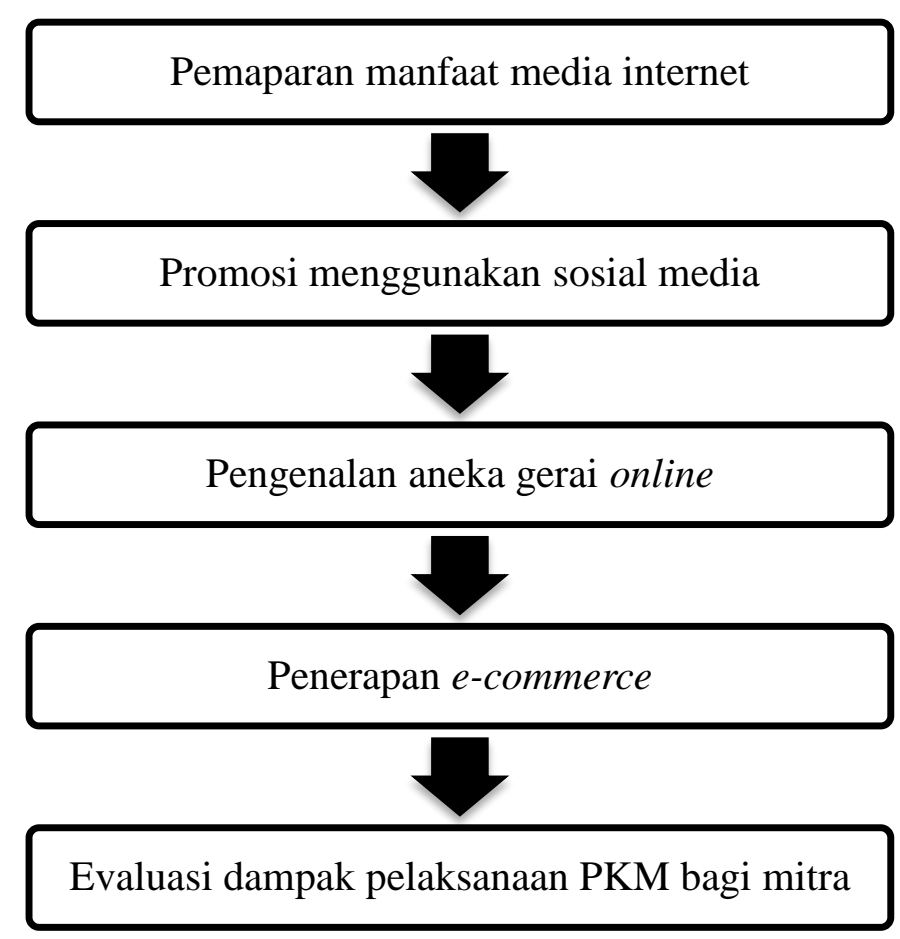

Gambar 1. Diagram alir pelaksanaan program kemitraan masyarakat.

Adapun penjelasan dari masing-masing diagram alir diatas sebagai berikut:

a. Pemaparan Manfaat Media Internet

Pada bagian ini pelaksana pengabdian mengadakan pelatihan guna memberikan wawasan pemanfaatan media internet yang mendukung usaha mereka. Pemaparan dampak positif dan negatif terhadap keberadaan media internet dan peluang usaha yang dapat dikembangkan. Selain itu mengajarkan cara mengetahui kompetitor dari usaha sejenis yang dikembangkan secara online melalui mesin pencarian, misal melalui google.com.

b. Promosi Menggunakan Sosial Media

Pada bagian ini dilakukan pelatihan untuk memanfaatkan sosial media untuk melakukan promosi produk. Banyaknya pertemanan di sosial media sangat mendukung penyebaran informasi produk. Hal ini merupakan upaya promosi yang baik yang dapat dilakukan mitra untuk memperkenalkan produknya ke masyarakat melalui dunia maya.

c. Pengenalan Aneka Gerai Online

Pelatihan pengenalan gerai atau toko online bertujuan untuk memberikan informasi bahwa mitra juga dapat menjual produknya melalui gerai atau toko online yang ada di Indonesia. Pada pelatihan ini mitra diinformasikan cara untuk registrasi dan melakukan transaksi pada salah satu gerai online.

d. Penerapan E-Commerce

Pada bagian ini pelaksana pengabdian kepada masyarakat mengenalkan aplikasi pemasaran berbasis web yang dapat digunakan oleh mitra dalam melakukan penjualan produknya secara online. 
e. Evaluasi Dampak Pelaksanaan PKM bagi Mitra

Evaluasi dilakukan terhadap dampak pemanfaatan aplikasi pemasaran berbasis web terhadap peningkatan penjualan produk mitra. Dampak peningkatan penjualan terhadap pendapatan mitra dan peningkatan layanan oleh mitra terhadap pelanggan.

Partisipasi mitra secara aktif dalam program kemitraan masyarakat ini mutlak sangat diperlukan karena nantinya aplikasi e-commerce yang dibuat akan digunakan seterusnya oleh mitra. Partisipasi tersebut bisa dimulai dari terbukanya mitra terhadap semua proses atau tahapan pelaksanaan program kemitraan masyarakat ini. Kegiatan program ini akan dilakukan di tempat mitra. Partisipasi mitra dalam proses pendampingan, pembuatan dan penyusunan aplikasi e-commerce, serta pelatihan dengan mengikuti semua proses dengan baik, maka diharapkan nantinya mitra akan dapat memahami hasil dari program ini dengan baik pula. Masukan dari tim pelaksana juga tak lain adalah demi terlaksananya kegitan program ini dengan baik serta aplikasi e-commerce yang dihasilkan dalam kegiatan ini akan benar-benar bermanfaat dan membantu bagi perkembangan usaha dari mitra.

\section{HASIL DAN LUARAN YANG DICAPAI}

Proses bisnis dari aplikasi e-commerce (toko online) yang telah dibangun dijelaskan pada gambar 2.

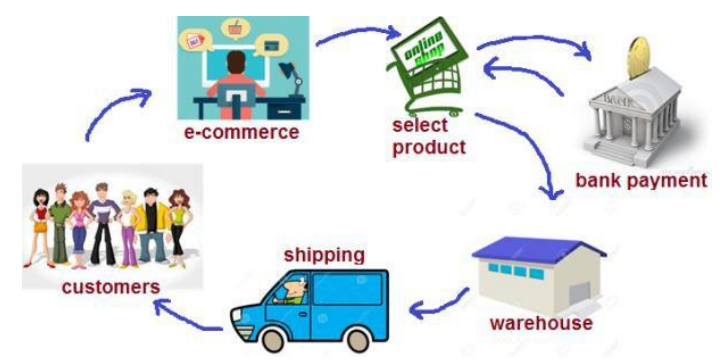

Gambar 2. Proses bisnis yang ada pada toko online Topeng Kona berikut:

Jadi, secara singkat proses bisnis penjualan online adalah sebagai

- Konsumen mengunjungi toko online kita.

- Konsumen menemukan barang dan melakukan transaksi pembayaran.

- Proses verifikasi transaksi pembayaran konsumen.

- Proses pengiriman barang ke konsumen.

- Adanya repeat order.

Alamat aplikasi e-commerce (toko online) yang telah dibuat adalah https://desty.store/topengkonacoffeeroastery, dengan nama toko Topeng Kona. Berikut adalah tampian dari toko online tsb: 


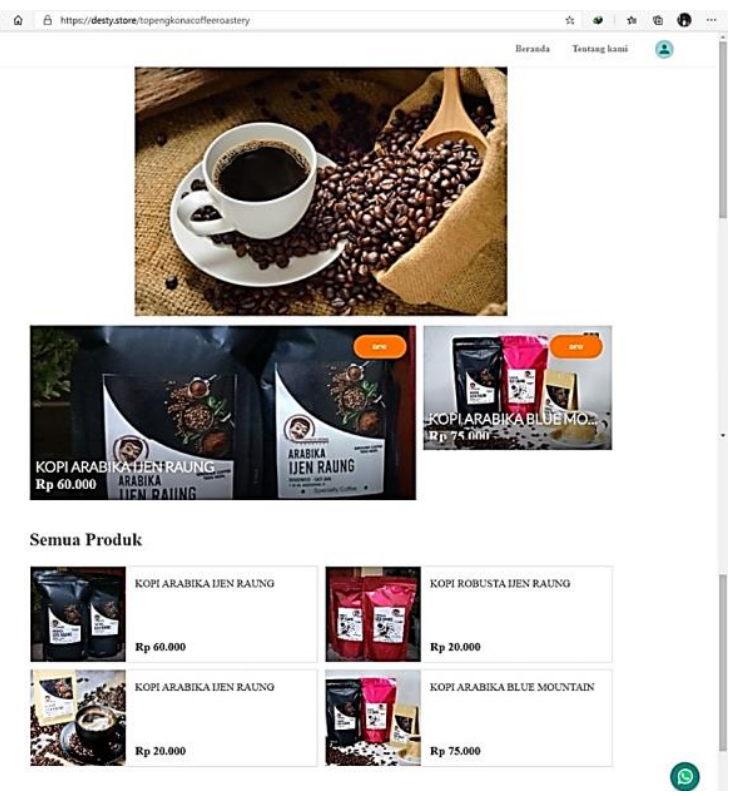

Gambar 3. Laman web https://desty.store/topengkonacoffeeroastery

Berikut bagian-bagian dari toko online :

a. Dashboard (Beranda)

Dashboard merupakan bagian untuk memaksimalkan promosi dan penjualan. Bagian ini digunakan untuk menyesuaikan desain toko, tambah produk, menentukan produk unggulan, keterangan tentang usaha UD. Topeng Kona Coffee Roastery dan produk, pilihan kurir, bagikan ke media sosial, dsb.

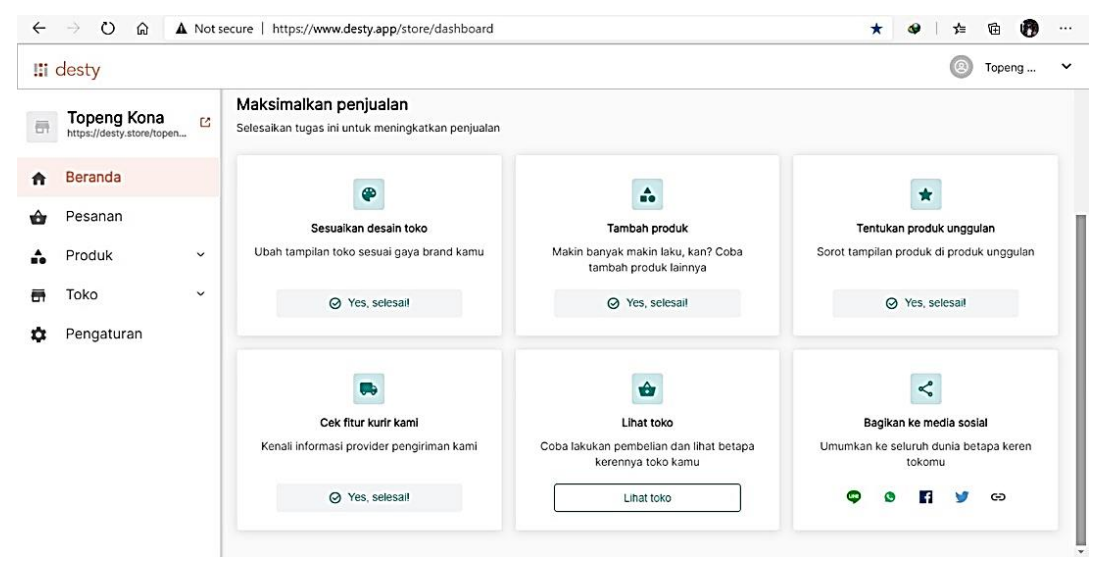

Gambar 4. Tampilan Dashboard pada toko online Topeng Kona

b. $\operatorname{Order}$ (Pesanan)

Order mencatat macam pesanan, jumlah pesanan dan status pesanan. Bagian ini juga mencatat jumlah total penjualan. 


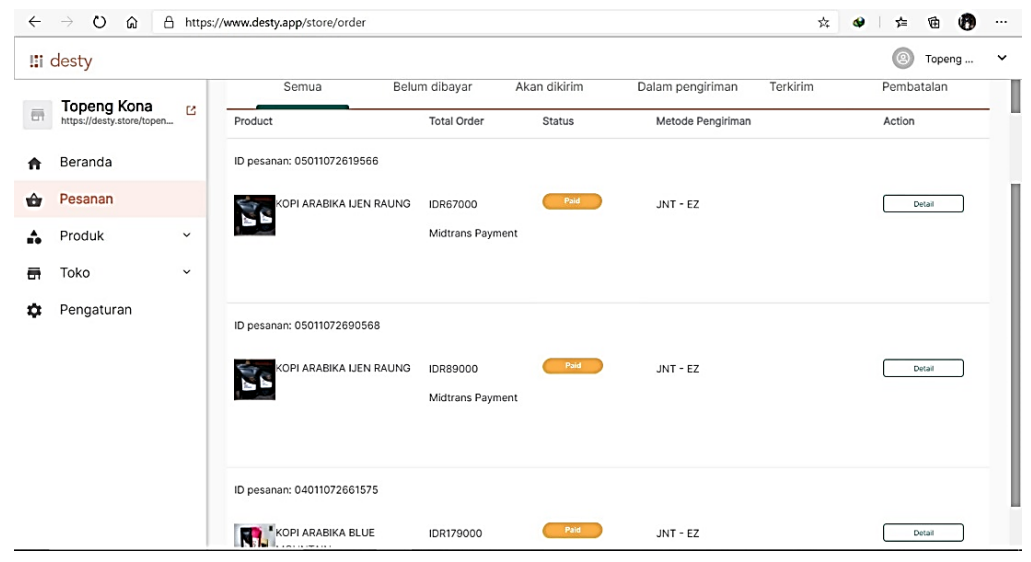

Gambar 5. Tampilan bagian order

\section{c. Product}

Bagian ini menampilkan nama produk, deskripsi produk, foto produk, variasi produk, harga dan stok dari produk yang dijual serta juga untuk memilih produk unggulan agar pelanggan mengetahui produk unggulan dari UD. Topeng Kona Coffee Roastery.

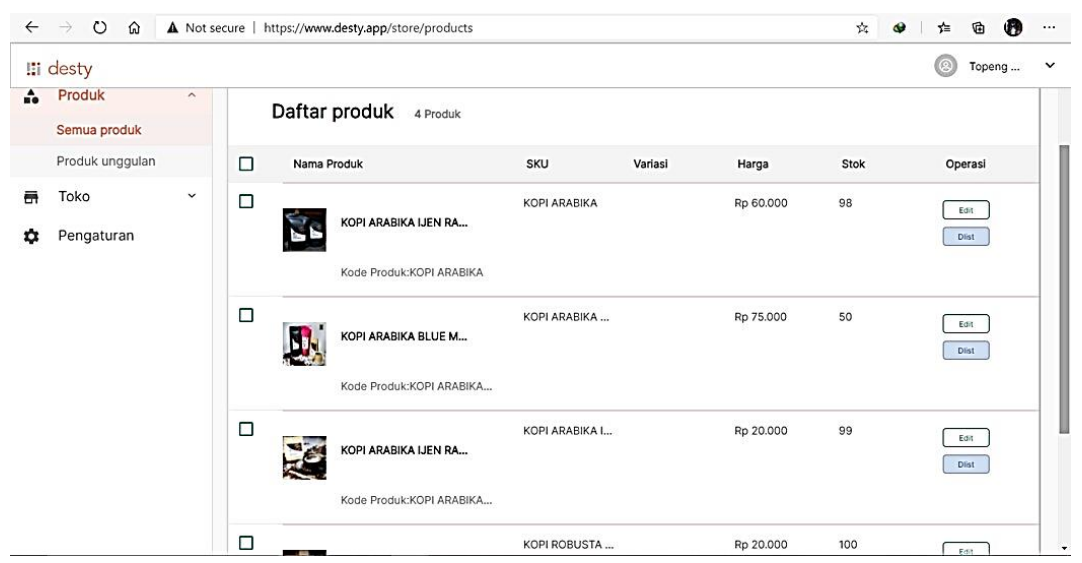

Gambar 6. Tampilan bagian produk

d. Toko

Bagian ini menampilkan design toko untuk mempercantik tampilan toko online yang telah dibuat. Terdapat layout dan banner yang akan memperindah tampilan toko online dengan menampilkan foto-foto produk di halaman tampilan toko online. Pada bagian ini juga memuat metode pembayaran, pilihan kurir serta detail toko online. 


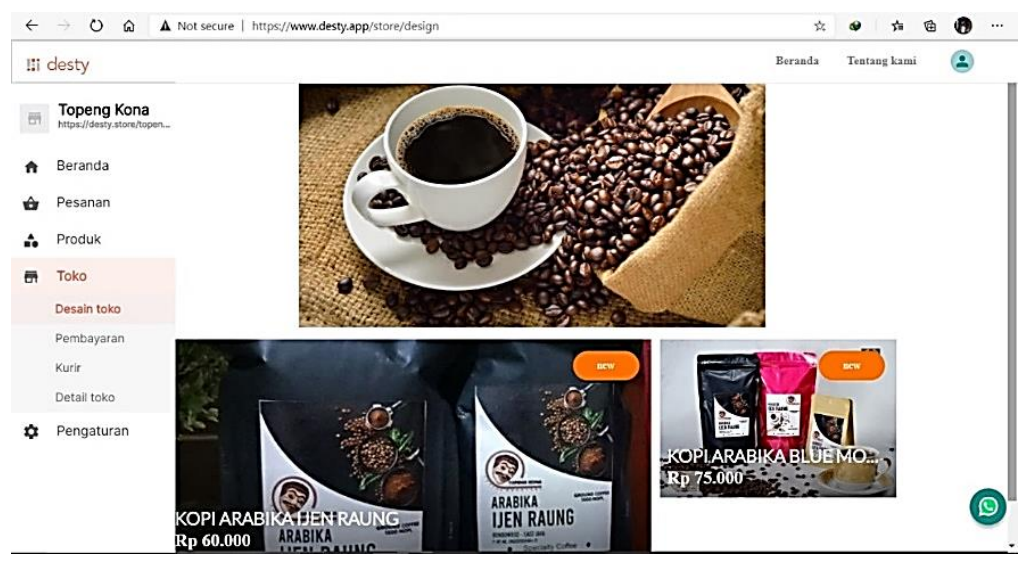

Gambar 7. Tampilan bagian toko

e. Setting (Pengaturan)

Bagian ini menampilkan bahasa toko dan akun, notifikasi untuk pelanggan serta notifikasi untuk penjual.

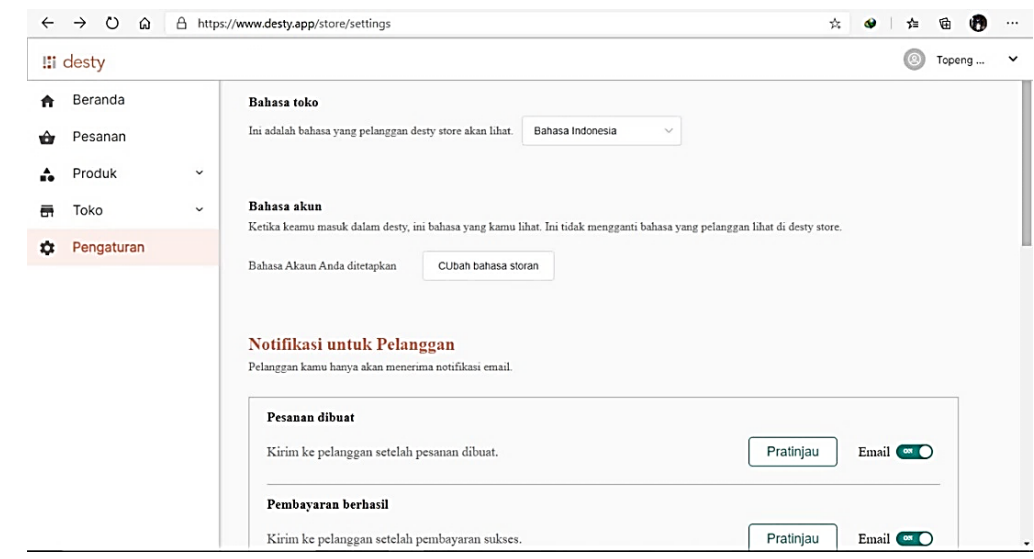

Gambar 8. Tampilan bagian setting

\section{f. Contoh Proses Transaksi}

Berikut contoh proses transaksi yang dilakukan pada toko online Topeng Kona: 


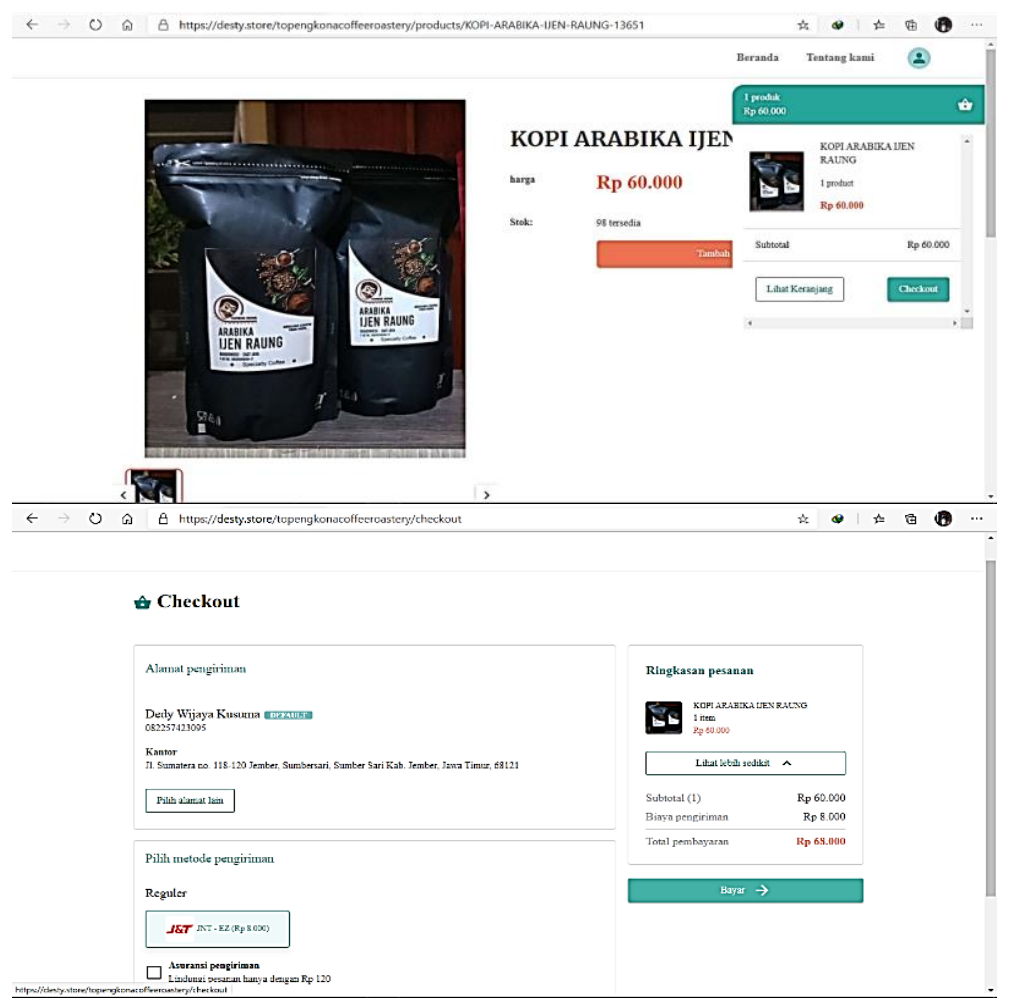

Gambar 9. Contoh transaksi

\section{g. Dampak Terhadap Penjulan Produk}

Dampak penggunaan toko online untuk membantu dalam proses promosi dan penjualan masih belum dapat dievaluasi secara detail karena toko online ini masih satu bulan diperkenalkan dan digunakan oleh UD. Topeng Kona Coffee Roastery. Namun keberadaan toko online Topeng Kona ini sudah dapat ditemukan pada mesin pencarian google. Hal ini juga dibuktikan dari orderan produk yang masuk, walaupun baru satu bulan berjalan tetapi sudah ada yang memesan produk kopi Topeng Kona ini yang berasal dari kota Semarang, Yogyakarta dan Bandung.

\section{KESIMPULAN}

Kegiatan PKM pemanfaatan aplikasi e-commerce untuk pemasaran kopi UD. Topeng Kona Coffee Roastery ini telah dapat dijalankan dan tanpa halangan berarti. Kegiatan PKM yang dilakukan ini telah sampai pada tahapan pembuatan dan pemanfaatan aplikasi e-commerce (gerai online) untuk digunakan sebagai media promosi maupun penjualan produk kopi yang dihasilkan oleh UD. Topeng Kona Coffee Roastery,sehingga diharapkan akam meningkatkan pemasaran dan penjualannya secara maksimal.

Proses transfer teknologi dengan mitra dapat dilakukan dengan suasana yang menyenangkan dan diskusi yang mampu memberikan wawasan terhadap pemecahan permasalahan mitra. 
Pada penerapan $e$-commerce terhadap produk kopi ini memang perlu diberikan wawasan terlebih dulu pada mitra tentang promosi menggunakan media internet sebagai media promosi sekaligus media pemasaran produk mitra sehingga akan meningkatkan pendapatan mitra. Selain itu juga perlu ditekankan untuk mempertahankan kualitas produk karena berhubungan terhadap kepercayaan pembeli, memberikan informasi lengkap dan cepat, serta keterbukaan terhadap informasi kepada pelanggan.

\section{DAFTAR PUSTAKA}

[1] Irmawati, D. (2011). Pemanfaatan e-commerce dalam dunia bisnis. Jurnal Ilmiah Orasi Bisnis-ISSN, 2085, 1375.

[2] Ngai, E. W., \& Gunasekaran, A. (2007). A review for mobile commerce research and applications. Decision support systems, 43(1), 3-15.

[3] Ahangari, Y. (2013). Naneh karan, An Introduction To Electronic Commerce. International Journal of Scientific \& Technology Research, 2(4).

[4] Niranjanamurthy, M., Kavyashree, N., Jagannath, S., \& Chahar, D. (2013). Analysis of e-commerce and m-commerce: advantages, limitations and security issues. International Journal of Advanced Research in Computer and Communication Engineering, 2(6), 2360-2370.

[5] Gangeshwer, D. K. (2013). E-commerce or Internet Marketing: A business Review from Indian context. International Journal of u-and e-Service, Science and Technology, 6(6), 187-194.

[6] Shahriari, S., \& Mohammadreza, S. (2015). E-COMMERCE AND IT IMPACTSON GLOBAL TREND AND MARKET. International journal of research-Granthaalayah, 3(4), 49-55. 